\title{
Retraction Note: Successful implementation of an enhanced recovery after surgery (ERAS) protocol reduces nausea and vomiting after infratentorial craniotomy for tumour resection: a randomized controlled trial
}

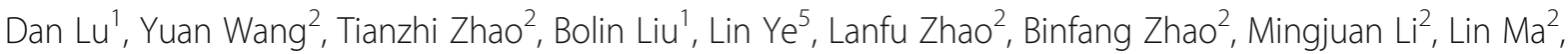 \\ Zhengmin $\mathrm{Li}^{4}$, Jiangtao Niư ${ }^{4}$, Wenhai Lv², Yufu Zhang ${ }^{2}$, Tao Zheng ${ }^{1}$, Yafei Xue ${ }^{2}$, Lei Chen ${ }^{1}$, Long Chen², \\ Xude Sun ${ }^{4}$, Guodong Gao ${ }^{1,2}$, Bo Chen ${ }^{3^{*}}$ and Shiming He,
}

\section{Retraction Note: BMC Neurology 20, 150 (2020) https://doi.org/10.1186/s12883-020-01699-z}

The Editor has retracted this article [1] because upon investigation the authors have been unable to provide documents confirming that ethics approval was obtained prior to study commencement. Further, numerous discrepancies have been found between the trial registration and the published article regarding recruitment dates, number of participants being recruited and age of participants. Finally, the authors have informed the journal that they included control data collected as part of a different trial. As such, the editor is no longer confident in the reliability of the data underlying the conclusions.

Author Dan Lu has stated on behalf of all co-authors that they agree to this retraction.

\section{Author details}

'Department of Neurosurgery, Xi'an International Medical Center, Xi'an, China. ${ }^{2}$ Department of Neurosurgery, Tangdu Hospital, The Fourth Military

\footnotetext{
The original article can be found online at https://doi.org/10.1186/s12883020-01699-z.

*Correspondence: slash0704@sina.com.cn; he-shiming@163.com

${ }^{3}$ Department of Neurosurgery, Shaanxi Provincial People's Hospital, Xi'an, China

'Department of Neurosurgery, Xi'an International Medical Center, Xi'an, China Full list of author information is available at the end of the article
}

Medical University, Xi'an, China. ${ }^{3}$ Department of Neurosurgery, Shaanxi Provincial People's Hospital, Xi'an, China. ${ }^{4}$ Department of Anesthesiology, Tangdu Hospital, The Fourth Military Medical University, Xi'an, China. ${ }^{5}$ Department of Nutrition, Tangdu Hospital, The Fourth Military Medical University, Xi'an, China.

Published online: 17 December 2020

\section{Reference}

1. Lu D, Wang Y, Zhao T, et al. Successful implementation of an enhanced recovery after surgery (ERAS) protocol reduces nausea and vomiting after infratentorial craniotomy for tumour resection: a randomized controlled trial. BMC Neurol. 2020;20:150 https://doi.org/10.1186/s12883-020-01699-z.

(c) The Author(s). 2020 Open Access This article is licensed under a Creative Commons Attribution 4.0 International License, which permits use, sharing, adaptation, distribution and reproduction in any medium or format, as long as you give appropriate credit to the original author(s) and the source, provide a link to the Creative Commons licence, and indicate if changes were made. The images or other third party material in this article are included in the article's Creative Commons licence, unless indicated otherwise in a credit line to the material. If material is not included in the article's Creative Commons licence and your intended use is not permitted by statutory regulation or exceeds the permitted use, you will need to obtain permission directly from the copyright holder. To view a copy of this licence, visit http://creativecommons.org/licenses/by/4.0/ The Creative Commons Public Domain Dedication waiver (http://creativecommons.org/publicdomain/zero/1.0/) applies to the data made available in this article, unless otherwise stated in a credit line to the data. 